\title{
A GLANCE ON THE ROLE OF HSIEN WU IN IMMUNOLOGY DEVELOPMENT
}

\author{
MOHAMMAD EBRAHIMI \\ Department of History of Science and Scientific Archaeology, \\ University of Science and Technology of China, People's Republic of China; \\ e-mail:ebrahimi@mail.ustc.edu.cn
}

Received: 13 April 2020; Accepted: 25 June 2020

Early in the $20^{\text {th }}$ century, a number of researchers in the field of immunology investigated this science chemically. Immunochemistry is the study of antigens and antibodies and their chemical basis and resistance to disease, developed from immunology. The immunochemistry period began in 1918 and continued through the early 1960s. Since the beginning of the immunochemical period, many researchers have been working in the field of immunochemistry by introducing important immunohistochemical and immunocytochemical methods. Hsien Wu was inspired by the science of immunochemistry and was able to determine a method for the determination of hemoglobin. In this article, I attempt to illustrate Hsien's achievements in this period by presenting Hsien Wu's scientific biography and immunochemical history. Furthermore, providing documentary and scientific information on the course of immunochemistry and the role of Hsien in this course may be a spark for some researchers to explore the reasons for some of the chemical approaches and theories of this period.

Ke ywords: Hsien Wu, immunology, immunochemistry, chemical approach.

$\mathrm{T}$ he names of Folin and Wu and their method of blood analysis are familiar to all students of biochemistry. However, the story of Hsien's life and his role in nutrition is not well known. Hsien Wu was born on November 24, 1893, in Foochow, China, to an educated family. At the age of six, he began his classical education under the tutorship of a family tutor. He completed the Fukien Provincial High School curriculum over four years. Hsien was very interested in science and learning, so he went to Beijing to take the exam to study in the United States. He was one of the 160 who received a scholarship to the United States that year and moved to the United States in 1911 and began his education at the Massachusetts Institute of technology. However, he [1] read articles such as "On the physical basis of life" [2] and found that science was his primary interest [1] and changed his field of chemistry and biology [2].

His undergraduate thesis was on Spermaceti derivatives [1]. After graduating with a bachelor's de- gree in 1916[2], Hsien completed his undergraduate degree in organic chemistry at MIT for a year and, at the same time, worked as a laboratory assistant [3]. In 1917 he entered Harvard University and did research under Dr. Otto Folin and obtained a doctorate [1]. Within two years, Hsien published his classic treatise [3]. His thesis was published in the journal of Biological Chemistry in 1919 as "Blood System Analysis". This research was the first of 159 scientific articles to be published by Dr. Wu in American and Chinese scientific journals [1]. He devised a method in which only $10 \mathrm{ml}$ of the blood sample could quantify the major constituents of blood. With his method, it was possible to measure the amount of sugar in the blood or urine with a sample of one drop [4]. In fact, scientists said that without the method invented by $\mathrm{Wu}$, insulin discover would not be possible. These analytical methods were later known as Folin-Wu methods [4]. There was a friendly competition between the Folin and Stanley Benedict groups for blood sugar determination. Following Hsien's

(C) 2020 Mohammad Ebrahimi. This is an open-access article distributed under the terms of the Creative Commons Attribution License, which permits unrestricted use, distribution, and reproduction in any medium, provided the original author and source are credited. 
method of blood glucose determination, Best and Banting discovered insulin [3].

In 1924, he married Daisy Yen, a biochemistry assistant at the Hsien Department, who studied under Dr. Henry C.Sherman at Columbia University [1]. Hsien's and his wife's studies on changes in electrolytes and water in the blood led to changes in the Duboscq colorimeter [3]. After receiving a doctorate at Harvard, Hsien was sent to the newly established Peeking Union Medical College (PUMC), where he taught and did research and was a professor until 1942 [5] for 20 years [4] and headed the biochemistry group [5]. Hsien Wu noticed the malnutrition of many Chinese and decided to improve the situation through scientific research. At PUMC, he began a systematic study of the relationship between food and human health. He reared the animals on a fully vegetarian diet and a comprehensive diet and endorsed the benefits of comprehensive meals. $\mathrm{He}$ further observed that the nature of the protein is crucial in observing diets containing protein in mice. He published the first food composition analysis in China and conducted the first nutritional survey and also set dietary indicators for all individuals [4]. In short, one of his goals was to improve the health of his countrymen, and in 1929 he wrote a Chineselanguage book on nutrition and revised it in 1938 [3]. His role in nutrition was significant, in addition to the publication of the Nutrition Book, he was a member of the Food and Agriculture Advisory Committee (1949-1948) and a member of the Required Calorie Committee (1949-1950) [1]. At the request of the Chinese national government, he set up a nutrition institute in Chungking in 1944, took over the management and two years later, at Nanking, he was director of the nutrition institute [1]. In 1948, he presented an article entitled "Nutritional deficiencies in China and Southeast Asia" at the Fourth International Congress of Tropical Medicine and Malaria in Washington [1].

Hsien and colleagues published 16 articles on protein denaturation. In 1931, Hsien published an article entitled "Studies on denaturation of the protein.XIII. A theory of denaturation", which played a prominent role in international studies on the protein [4]. Chemist Felix Haurowitz stated that Hsien was the first used labeled antigens to determine proteins in the presence of antibodies, and he was the first suggested that peptide chains in globular proteins fold and appear as denaturation [4].

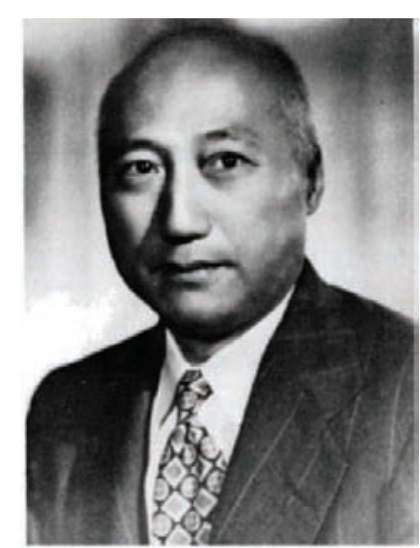

Hsien $W u[3]$

Hsien went to Columbia University as a researcher in 1948. He and his family (five children) were forced to reside in the United States permanently because of the war and the demolition of his home by the Communists [1]. International co-operation was an essential part of Hsien's activities, such as attending meetings of the International Congress of Physiology in Boston (1920), Rome (1932), Moscow (1935), and Oxford (1947) [3]. He has written and published 163 scientific articles and three books. He was a member of the American Society of Biological Chemists and was an honorary member of the German National Academy of Sciences Leopoldina [4].

In general, it can be said that the Hsien research areas include [6]:

- Blood chemistry.

- Gas and electrolyte equilibria.

- Nutrition.

- Immunochemistry.

- Proteins.

- Metabolism of amino-acids labeled with nitrogen-15 as a tracer.

- Molecular weights and osmotic pressure of hemoglobin of experimental animals.

His most recent study on $\mathrm{N}$ excretion pattern followed the consumption of labeled amino acids [1]. Hsien Wu retired in 1953 after breaking the Crohn's thrombosis [4] and died on August 10, 1959, at a hospital in Philips. He was 65 at the time of his death and lived in Boston [4].

\section{Immunology period}

The course of immunology is divided into three separate sections, since World War I centered on new bacteriology and infectious diseases, in 1880, 
and was purely medical. Outcomes of this course include presenting new vaccines, therapeutic approaches, studying cellular immunity, and investigating diseases that are likely caused by cytotoxic antibodies. After this period, a new group of chemically oriented researchers began studying antigens and antibodies [7].

Karl Landsteiner was the only prominent oldtimer in the new era of immunology. This course of immunology was not widely associated with many different fields of biology and medicine. This is the period from World War I to the late 50s and early 1960s. After this period, there was a sudden shift in the field of immunology, which may be called a scientific revolution. Chemical approaches and theories were quickly overthrown by a new clonal biomedical paradigm, at which time a different set of questions arose, including the biological basis and biomedical implications of the immune response [7].

Finally, chemist studying on the end-product molecule and biologists investigating early cellular interactions found common ground in the molecular biology of T-cell receptors and lymphokines and worked together to explain and explain it. This is the field of antibody formation and cell-cell interaction. The broad implications of this alliance between chemists and biologists were called the immune system and discussed in detail by A. M. Maluin[7].

\section{Manifest and development of immunology}

Historians in Athens in the fifth century BC cite Thucydides as the first immunity from the plague. The notion of immunity to the disease may have existed long ago, as according to ancient Chinese tradition, skin lesions of patients who had been vaccinated with smallpox were used to make children resistant to smallpox [8]. Immunology, in its modern form, is an empirical science in which explanations of the immunological phenomena are presented on the basis of empirical observations and their conclusions. The evolution of immunology as a laboratory depends on the ability of scientists and researchers to manipulate immune function in controlled conditions. Historically, the first prominent example of this manipulate was made in 1796 by Edward Jenner [8].

Jenner is an English physician who successfully vaccinated against smallpox. He realized that milkmaids who had recovered from cowpox never contracted severe smallpox. Based on this observation, he injected the material from a cowpox pustule into the arm of an 8-year-old boy. When later, this boy deliberately did not develop the disease with smallpox, inoculated. Jenner's landmark treatise on vaccination was published in 1798 . This led the researchers to concede that this method is useful for developing immunity against infectious diseases and that vaccination is the most effective way to prevent infections. In 1980, the World Health Organization announced that smallpox was the first disease to be eradicated by vaccination worldwide [8].

\section{Beginning of immunochemistry era}

About 100 years later, in 1890, German physiologist Emil von Behring discovered serum antibodies for the treatment of diphtheria and tetanus [9]. In 1906, F. Obermayer and Pick found that the injection of iodinated protein produces two types of antibodies. One of these antibodies works against tyrosine iodination residues and the other against protein fragments. These experiments led to the use of chemically marked antigens in Karl Landsteiner's outstanding research [9]. However, the term immunochemistry was coined in 1907 following Arrhenius's explanation. In his explanation, it is stated that immune reactions as analogous to the combination of weak acids with weak bases [10]. Until 20 years after Arrhenius was introduced, no serious attempt was made on alternative measurement methods in the field of immunochemistry [10]. Arrhenius's work in the field of immunochemistry was an attempt to study more toxin-antitoxin reactions in diphtheria reactions using concepts and methods developed in physics chemistry. Arrhenius worked for a short time and gradually abandoned the field [10]. In fact, it can be said that the study of antigens and antibodies and the chemical basis of immunity and disease resistance have been developed from immunology and still use its methods and nomenclature [10].

\section{Hsien Wu contribution in immunochemistry}

Until 1927, Hsien Wu, Cheng L.H., and Li C.P. used the micro-Kjeldahl method to estimate the amount of hemoglobin deposition by anti-hemoglobin. But their results were incorrect in specifying fixed composition with different ratios of antigens and antibody [11]. The use of immunochemical methods is far beyond the study of immunity to disease and has become a valuable tool in the characterization of proteins and polysaccharides and is an integral part of protein chemistry 
[10]. Since the beginning of the immunochemistry period, many researchers have been working on the introduction of important immunohistochemical and immunocytochemical methods in the field of immunochemistry [9]. Immunohistochemistry is the process of detecting antigens (e.g., proteins) in cells of a tissue segment using monoclonal and polyclonal antibodies. This method was first introduced by Arrhenius in 1941 but was also present in the 1930s [12].

In $1931 \mathrm{Hsien} \mathrm{Wu}$ was the first scientist to understand the fundamental relationships between the native and denatured state of the protein molecule. The critical point of his theory is that a native protein molecule is in a highly compact and well-ordered structure that is primarily held by the interaction between the polar groups in the main chain and the polar side chains [5].

In 1929, slightly more extensive data were provided by Michael Heidelberger, Kendall, and F.E.J. They used the nitrogen-free carbohydrate antigens. The amount of antibody was calculated from the amount of nitrogen deposited, which in turn was determined using the Kjeldahl method and later by calorimetry according to Lawry or by ultraviolet absorption at approximately $280 \mathrm{~nm}$ [9]. In 1930, Breinl F. and Haurowtiz F.Z. used gravimetry with microbalances to determine the total weight of the sediment. The amount of antigen was measured using calorimetric [9].

Hsien, Kuo-Hao Lin and Tung-Tou Chen investigated the mechanism of denaturation by comparing the amount of digestion by natural pepsin and trypsin of ovalbumin with proteins that were denatured. They used crystalline ovalbumin from egg whites for this study and examined its denaturation and dialysis. Factors used for denaturation included acid, alcohol, alkali, heat, and vibration. After making a series of corrections to the nitrogen from the enzymes, they calculated the percentage of total digested nitrogen. They stated optimal $\mathrm{pH}$ and the maximal digestion of the different proteins in their research paper [13].

They found that in the peptic series, the digestion rates of natural and different forms of denatured proteins were the same except for a few cases. This indicates that the fundamental changes underlying denaturation do not affect those linkages in the albumin molecule, which are hydrolyzed in peptic digestion. They announced that the changes produced by the denaturing are in the direction of degrada- tion and probably of the same nature as tryptic digestion. In addition to these results, Hsien and his colleagues demonstrated that denatured and natural proteins differ in optimal $\mathrm{pH}$ digestion. In light of this hypothesis, our findings seem to indicate that the isoelectric point and the maximal dissociation of the albumin are shifted toward the neutral point by denaturation [13].

Hsien Wu, Lan. Hua Cheng and Cheen-Pien Li introduced the method of determining hemoglobin. This method is based on the benzidine reaction with a low content of $0.02 \mathrm{mg}$. It is sufficient to determine the amount of hemoglobin to determine the antigen-precipitin composition. If hemoglobin is used as an antigen, its amount in antigen-precipitin can be determined directly by the benzidine reaction. The amount of precipitin in the precipitate can be determined by the difference between total protein and hemoglobin. However, it is assumed that the precipitate contains only antigen and precipitin with no other proteins. It should be noted that in the study of Hsien et al., hemoglobin means the general oxyhemoglobin and its immediate derivatives. Oxyhemoglobin on standing is slowly converted into methemoglobin. This is not important because oxyhemoglobin and methemoglobin have the same safety properties. Sheep oxyhemoglobin solution was prepared using water-washed cells (4 times the volume of cells) and shaking with $2.5 \%$ fresh aluminum hydroxide suspension. The final solution, after Seitz filter and Stadie's electro dialysis, contained $5 \%$ hemoglobin. Hsien and his colleagues tried different methods to immunize rabbits, but none were completely satisfactory. Only 15 out of about 50 rabbits gave usable sera. This was due to the antigenic properties of hemoglobin. The $\mathrm{N}$ content of stock hemoglobin solution, from which the dilute solutions were prepared, was also determined. Based on the results obtained, Hsien and colleagues stated that the antigen-precipitin deposition was a constant compound and the reaction between the antigen and precipitin was chemical and not purely physical or colloidal [14].

Hsien (1893-1959) was a renowned biochemist and nutritionist with excellent achievements in protein chemistry, clinical chemistry, immunochemistry, nutrition, and more. He was also the founder of Biochemistry and Nutrition in China and is known as the Chinese chemist giant and the greatest chemist and perhaps the well-known Chinese scientist in the first half of the $20^{\text {th }}$ century [4]. The immunochemi- 
cal period began with a debate between Paul Ehrlich, Landsteiner, and Arrhenius. Arrhenius coined the name of immunochemistry in 1907 [11] and focused on toxin-antitoxin reactions [3]. Meanwhile, Hsien and his colleagues, using the science of immunochemistry, found useful ways to overcome protein denaturation and quantitative chemical methods of analysis were shed light on further development in immunochemistry [4-10].

Conflict of interest. Authors have completed the Unified Conflicts of Interest form at http://ukrbiochemjournal.org/wp-content/uploads/2018/12/ coi_disclosure.pdf and declare no conflict of interest.

Acknowledgments. I would like to thank my supervisors, professor Shi Yunli and professor. Bartlomiej Swiatczak, for the support of my PhD study and research.

\section{ПОГЛЯД НА РОЛЬ СЯНЬ ВУ В РОЗВИТКУ ІМУНОЛОГІї}

\section{Mohammad Ebrahimi}

Department of History of Science and Scientific Archaeology, University of Science and Technology of China, People's Republic of China; e-mail: ebrahimi@mail.ustc.edu.cn

На початку 20 століття, дослідники в галузі імунології вивчали цю науку з хімічної точки зору. Імунохімія - це дослідження антигенів і антитіл та хімічних основ імунологічних явищ. Період активного розвитку імунохімії розпочався у 1918 році і тривав до початку 1960-х років. 3 початку цього періоду, у галузі імунохімії було впроваджено важливі імуногістохімічні та імуноцитохімічні методи. Китайський біохімік Сянь Ву, натхненний імунохімією, запропонував метод визначення гемоглобіну. У цій статті здійснено спробу проілюструвати досягнення Сянь Ву, представлено його наукову біографію та погляд на історію імунохіміі. Крім того, надана документальна та наукова інформація щодо розвитку імунохімії та ролі Сянь Ву може бути для вчених надихаючою силою для вивчення закономірностей появи деяких хімічних підходів та теорій цього періоду.

К л ю ч о в с ло в а: Сянь Ву, імунологія, імунохімія, хімічний підхід.

\section{References}

1. Hsien Wu. Nutr Rev. 1974; 32(10): 319.

2. New York Times. (1959). DR. HSIEN. WU, 65, Blood Specialist; Biochemist, Co-Developer of Analysis Method, Is Deadw . Taught at U. of Alabama, p. 27. Retrieved from https://www. nytimes.com/1959/08/10/archives/d-r-hsien-wu65-blood-specialist-biochemist-codeveloper-ofanalysis.html

3. Bishop C. Hsien Wu (1893-1959): A biographical sketch. Clin Chem. 1982; 28(2): 378-380.

4. Zheng S. Hsien Wu, the founder of Chinese biochemistry and nutriology. Protein Cell. 2012;3(5):323-324.

5. Edsall J. Hsien Wu and the First Theory of Protein Denaturation (1931). Adv Protein Chem. 1995; 46: 1-5.

6. Carmichael EB. Dr. Hsien Wu. Nature. 1960; 185(4716): 809-810.

7. Silverstein AM. The dynamics of conceptual change in twentieth century immunology. Cell Immunol. 1991; 132(2): 515-531.

8. Rees A. The antibody molecule. Oxford: Oxford University Press, 2015. 364 p.

9. Haurowitz F. The origin and development of immunochemistry (1890-1965). Trends Biochem Sci. 1979; 4(11): N268-N270.

10. Kabat EA, Mayer MM. Experimental immunochemistry. $1^{\text {st }}$ ed. Charles Thomas Publisher. USA. 1948

11. Heidelberger M, Kendall FE. The beginnings of quantitative immunochemistry. Trends Biochem Sci. 1979; 4(7): 168.

12. Orakpoghenor O, Avazi DO, Markus TP, Olaolu OS. A short review of immunochemistry. Immunogenet Open Access. 2018; 3(122): 2.

13. Lin KH, Wu H, Chen TT. Effect of denaturation on digestibility of ovalbumin by pepsin and trypsin. Exp Biol Med. 1927; 25(3): 199-200.

14. Wu H, Cheng LH, Li CP. Composition of Antigen-precipitin Precipitate. Exp Biol Med. 1928; 25(9): 853-855. 